\title{
8 Masculinity in contemporary Viking and Samurai comedies: 'It's not really me, that fear-based leadership style stuff'
}

\author{
Jennifer Branlat and Priscilla Ringrose
}

\section{Living up to modern masculinities}

In this chapter, we examine contemporary TV comedies about Norwegian and Japanese manhood in crisis. Norsemen (original title: Vikingane; 2016) is a Norwegian comedy series about a group of vikings living in Southern Norway around the year 790 C.E. The series is a high-quality production with a rich visual texture that parodies the ultra-realistic diegetic worlds of more pretentious blockbusters, such as Vikings (2013-2020) and Game of Thrones (2011-2019). The characters are clad in period dress, with an emphasis on draping wool and well-worn leather. Norsemen was filmed at a location in a coastal village in Norway, and it was recorded simultaneously in both Norwegian and English-language versions by filming each scene twice. Its humour is delivered in a Monty Pythonesque deadpan style. The series premiered in Norway on the national TV channel NRK and was later aired on Netflix in both Norwegian and English. Samurai Shifters (original title: Hikkoshi Daimyo!, 2019) centres around a community of samurai living in the Himeji domain of southeast Japan in the 1680 s, during the Edo period. Released in 2019, the comedy features a star-studded cast, including the musician Gen Hoshino in the leading role. The film follows many of the codes and traditions of the familiar jidaigeki, or period drama, in its foregrounding of honour, sacrifice and sword-fighting. Although the jidaigeki genre influences the overall narrative structure, it is playfully ridiculed in farcical moments of subversion.

Norsemen and Samurai Shifters tell stories about the difficulties of living up to contemporary societal expectations concerning manhood. They give these stories a comic twist by transposing the characters back to a distant past - the Viking Age (800-1050) and the Edo period (1603-1867) - eras, which as represented in popular culture, are famously unconcerned about matters like gender equality, being a good partner and the equal sharing of domestic duties. The main characters of these comedies repeatedly find themselves in dilemmas that pit their millennial sensibilities against the values of the past: How can you be an effective leader when you are an introvert, bibliophile, recluse? How can you relocate an entire clan over a 


\section{4}

vast territory when you rarely leave your living quarters? Is it possible to be an intimidating warrior and still be sensitive enough to attend poetry readings with your wife? The protagonists perpetually and comically find themselves at odds with what society expects of them.

A brief look at the opening sequences shows how the films' creators frame the spectator's entry into the narrative space. In the opening sequence of the Norsemen, Arvid, the main character, is torn between his love of raiding and his desire to settle down. As his ship nears home, he confides in his chieftain superior:

Can't exactly say I'm looking forward to coming home now...My focus has always been on pillaging and ravaging and things like that, when all the other guys have settled down with wives, kids, farms and stuff. I'm feeling kind of alone here. (Helgaker \& Torgersen, 2016)

From Arvid's initial apprehension, the series proceeds with a satirical exploration of the unrealistic pressures to be the 'perfect man.' In a similar staging of masculinity and impossible expectations, Samurai Shifters opens with a hand drawn map that foregrounds the daunting task given to Katagiri, the unlikely 'shut in' samurai: Faced with limited time and budget, he is tasked with executing a master plan for the clan's distant relocation across land and water. As parodies or spoofs on the historical action drama, these narratives are less concerned with reproducing an accurate version of the past than they are with poking fun at the present.

In this context we understand film as a social practice that 'constructs narratives and meanings,' which enable us to 'locate evidence of the ways in which our culture makes sense of itself' (Turner, 2006, p. 3). Our decision to bring comedy into a discussion of masculinity reflects an attempt to liberate discussions of manhood from its polarising formats in media debates. We have also taken comedies from two different national contexts in the hopes that readers will come to see their common project: To defamiliarise contemporary societal expectations concerning masculinity. By taking the imperatives and pressures related to 'caring,' 'sensitive' manhood and staging them in a past dominated by representations of militaristic, hegemonic hierarchies - far from today's preoccupations with 'gender equality' or 'work-life balance' and 'caring fathers' - a comic effect is achieved. The comedy genre therefore allows us as spectators to step out of the realm of 'political correctness' operating in daily life and laugh at our own cultural attitudes, practices and their excesses. In this way, the process of defamiliarisation opens up a space between spectators and their own culture, a space in which reflection can occur in a playful manner. We ask: What dimensions of modern masculinities do these comedies explore? To what degree do these comedies uphold or challenge the prevailing social orders in Japan and Norway? Are there any similarities and differences that can be found in the representations of masculinity? 


\section{Theoretical framework}

Theories of humour and comedy have remained relatively stable over past decades, even as humour - most prominently over the past decade in the form of American satirical news programs - has come to the fore as an important 21 st century tool for social and political critique. In this chapter, we draw from social theories of humour which call attention to the relationship of comedy to broader social discourses. Incongruity theory, one of three main strands of humour theory, is useful for this purpose. As Critchley noted in his work On Humour, 'in order for the incongruity of the joke to be seen as such, there has to be a congruence between joke structure and societal structure - no social congruity, no comic incongruity' (2011, p. 3). He further reflected that 'humour returns us to common sense; by distancing us from it, humour familiarizes us with a common world through its miniature strategies of defamiliarization' (p. 17). By 'common sense,' Critchley is referring to the social codes, rules and understandings that communities share. For the gender-related humour explored in this chapter, the comic relief is produced by seeing the obvious similarities between the contemporary welfare state with its discourse on gender equality and the viking settlement staged in Norsemen. Similarly, Samurai Shifters activates our common understanding of figures like the samurai, salaryman and the hikikomori, a concept referring to a severe form of social withdrawal, and it depends on our judgement that a bikikomori young man would be ill-suited for the grand exploits required of samurai nobles during the Edo period.

The idea that humour can be seen as an important factor in the production of meaning in a given culture is also presented by Michael Mulkay in his well-known book entitled On Humour: Its nature and its place in modern society (1988). His theorising of humour is based on two fundamental modes: The 'serious mode' and the 'humorous mode.' In the humorous mode, there are plural realities (i.e., no one discourse has the upper hand) allowing for different discourses to coexist within the same context, unapologetically showcasing the contradictions, flaws and pretension of a 'serious' discourse. Both Norsemen and Samurai Shifters can be regarded as functioning in the 'humorous mode' as gender comedies that expose the tensions and contradictions in current societal discourses on femininity and masculinity.

Finally, within comedy studies, 'stereotypical humour' has been seen as particularly taboo because it often serves as a vehicle to ridicule marginalised groups. In a bold and ground-breaking work on the perils of racial, ethnic and gender humour, Leon Rappoport explains that this type of humour is more complex and much less straightforward and unidirectional than one might believe $(2005$, p. 2). It is above all characterised by ambiguity and is highly context dependent: It can involve any constellation of minority versus minority, majority versus majority, urban versus rural, 
women versus men and vice versa. Its 'appropriateness' may be determined by its proximity to mainstream attitudes (Rappoport, pp. 2-3). Our aim in drawing from Rappoport's reflections is to show that the extreme nature of many of the stereotyped figures in Norsemen and Samurai Shifters make them recognisable and yet so distant from what is culturally acceptable that it becomes laughable.

\section{Masculinity in Norway and Japan}

Recent literature on masculinity in both national contexts has brought to light the diversity of emerging masculinities, locating the 21 st century as a time of intense change for both Norway and Japan. The literature on visual representations of Norwegian masculinity over the past two decades has tended to crystallise around particular types of images: Caregiving fatherhood as a means to become a 'worthy' member of the national community (Dancus, 2011), immature and anxious men in a broader Western context of a 'crisis of masculinity' (Donnar, 2015) and intrepid, viking masculinity in the resurgence of the explorer drama (Sandberg, 2019). In terms of Norwegian masculinity exported to an international audience, one may look to Kristofer Hirvju's role as Tormund Giantsbane, the bearded raider of HBO's Game of Thrones (Benioff \& Weiss, 2011-2019). In interviews featured in the Norwegian media, Hirvju insisted on the difference between his off-screen identity as a supportive partner to a woman with a highcommitment career and a caring father, and his on-screen persona as a dreaded warrior and raider (Marthinussen, 2018).

In Norway, there is a lack of research exploring men's experiences such as those brought to light in interviews with Hirvju: The ideals of work-life balance, 'having it all' and being a good parent and supportive spouse. This lack may owe to the tenor of contemporary debates that focus on men's failings or different dimensions of masculinity viewed separately rather than holistically. The comic effect of Norsemen lies partly in the clash of two kinds of masculinity: A masculinity oppressed by the intimidating task of 'having it all' and meeting all the requirements of a gender-equal society in the 2000s, and the stereotypical hegemonic masculinity of the Viking Age associated with warrior militarism, 'risk-taking, the enforcement of command structures and disciplinary hierarchies, physicality, aggression, violence, and overt expressions of heterosexuality' (Hinojosa, 2010, as cited in Raffield, 2019, p. 818).

In Japan, research on masculinity over the past decades has revealed more nuanced and fine-grained understandings of Japanese masculinity, intentionally displacing the 'salaryman' as the dominant stereotype:

If (representations of) the middle-class, white-collar, heterosexual salaryman powerfully invoke(s) ideologies of national, class and sexuality in Japan, the practices and performance of other people must be seen as acts of challenge and change -potential, playful or purposeful. (Roberson \& Suzuki, 2003, p. 5) 
In the post-war period of economic growth, the salaryman became synonymous with hegemonic masculinity in Japan, symbolising the kigyō senshi or corporate warrior (Dasgupta, 2010, 2013; Hidaka, 2010; Sugimoto, 2010; Vogel, 1963). Masculinity scholar Futoshi Taga (2006) paints a vivid vignette of the stereotypical salaryman, recognisable to most Japanese people:

He is working for a large company or in the public sector and living a middle-class life with a wife and two children in an urban area; his wife is a housewife or a part-time worker, and he is expected to be the breadwinner of the family; he enjoys the benefits of lifetime employment and the seniority-promoting system; in exchange for these benefits, he has a strong sense of loyalty to his workplace and works long hours every day; he is also busy in the evening and on weekends at business entertainment events or associations with colleagues, so he scarcely does much housework or child care; his uniform is a dark suit. (p. 108)

While this figure has been intrinsically linked to Japan's process of industrialisation and nation-building, its antecedents may be traced back as far as to the Edo period. Much like the samurai warrior, the salaryman would be expected to display qualities related to the bushido code requiring loyalty, dedication and self-sacrifice. The economic downturn of the 1990s, however, fuelled doubt about the salaryman's efficacy. More recently, as Taga (2013) points out, factors such as 'globally-expanding feminist agendas,' the equation of masculinity with work, underpinned by stable connotations of gender, class, sexuality and nation, have all been challenged (p. 1). This problematising of the whole equation of masculinity and work (and the equation of femininity with the household) in Japan has emerged in various social, political and cultural arenas and is evidenced in academic and popular writings, in recent television programs focusing on issues like datsu-sara (leaving white collar work to start up one's own enterprise) and even in official publicity campaigns (Dasgupta, 2010). The relationship between masculinity and work has been most seriously interrogated in the figure of the ikumen or 'Japanese child caring men,' the object of a government campaign to get more men to actively participate in child rearing (Ishii-Kuntz, 2019).

In their work on masculinity in Japan, Roberson \& Suzuki (2003) argue the salaryman's dominance - a phenomenon they call the 'ideological hegemony of homogeneity' - has left other forms of masculinity unexamined (p. 4). While in the late 1990s it could be claimed that Japanese popular culture reinforced the salaryman's hegemony in the cultural landscape, today academic and popular texts as well as recent television programs challenge this. For example, TV dramas focusing on issues like datsu-sara have contributed to representations of the diversity of masculinity in Japan. 


\section{Jennifer Branlat and Priscilla Ringrose}

Samurai Shifters fits in this movement, with its playful (un)coupling of the salaryman's associations with the samurai. Director Inudō Isshin positions the counter-figure of the hikikomori as achieving success, thanks to his nonsamurai qualities: Vulnerability, shyness, lack of ambition and lack of combat skills.

\section{Norsemen and Samurai Shifters: Sensitive men wielding weapons}

In Norsemen, viking warriors return from their raid in the south with treasures and slaves, having found a map to a new world of wealth. Season one centres around the tough viking Chief Olav, his hapless brother Orm, Orm's wife (the feisty Frøya) and the conflicted warrior Arvid. Back on land after his voyage, Arvid plans to set himself up with a wife and farm - he has neither - and decides to challenge a local farmer for his wife Liv and land. Arvid then literally slices the unfortunate farmer in half before proceeding to take over his household and marry Liv to quell his anxieties about how he will measure up compared to peers who have already settled down with farms and families. But in spite of his new acquisitions, Arvid struggles to adjust to social life on land and the responsibilities it entails. His warrior skills are put to use defending the village, but in the private sphere he remains stuck as the quintessential henpecked husband. He fails to be a good enough partner to the demanding Liv, not least because she insists on his presence at home, forcing him to leave work on time to attend poetry evenings with other couples.

Norsemen therefore stages Arvid in a comic work-life balance dilemma that raises questions at the core of his identity and critically calls into question the demands of modern relationships. This dilemma forces Arvid to confront his own ideas about being an attractive mate, the importance of material possessions and meeting societal benchmarks for men. Once home, he discovers the difficulties of serving Orm, an incompetent boss while maintaining a healthy work-life balance in partnership with his nagging wife Liv. In particular, he wrestles with the task of being a culturallysensitive partner who can participate in Norheim's poetry club with other couples. Others admonish him for his lack of interest in 'finding other couples to hang out with.' The poetry club scene with Liv, Arvid and the other more cultured couples of Norheim serves to reinforce Arvid's feelings of isolation as he is asked to read his own poem out loud (Helgaker \& Torgersen, 2016):

Liv: So, maybe Arvid, you can read yours? Do you have a poem that is dear to your heart?

Arvid: One two three

Take out your wee wee

Four five 
Grab your bride

Six seven eight

Open up her gate

Nine ten

Fuck her then!

With Arvid's poetry leaving everyone aghast, he is ridiculed among Liv's sophisticated friends, thus prompting self-reflection about whether he can actually achieve anything in his private life.

Satirising platitudes and banalities serve as a frequent comic device in Norsemen as men grasp at seemingly 'wise' words to cope with their difficulties or justify their shortcomings. Arvid declares, in an attempt to boost his sexual self-confidence, 'It's not about the size of the boat, it's about the motion of the ocean.' Other male characters use truisms, statements that sound profound but are so obviously true that they preclude further discussion, that sound as if they come straight from self-help books on relationships or leadership. For example, Olav advises Arvid, 'You mustn't lose yourself in the relationship' to which Arvid responds, 'You know about relationships. It's about give and take.' Orm, in particular, as he takes over as Chieftain in the most incompetent manner possible seems to be making it up as he goes: 'And punctuality is a virtue. Which is something I've decided to start saying.' Other truisms sound like they come from current trends in Anglo-American leadership coaching: 'Be a little solution-oriented,' or 'You have to prioritise.' As spectators, we are encouraged to see these platitudes as comically insufficient coping strategies to deal with a perplexing masculine condition. It is certainly not from truisms that the male vikings will be able to derive some sort of meaningful life guidance.

When Chief Olav decides to leave on a new pillaging mission, the village changes dramatically as his weakling brother Orm takes over. Freed from his aggressive brother's oversight, Orm seizes the opportunity to lead the village in another, more cultured direction. In a satire on largesse and hierarchy, he appoints his slave Rufus as creative director. Next, Orm orders all villagers to surrender their weapons to Rufus in order to create an art installation. Unfortunately, this decision leaves the whole clan vulnerable to attack. As the foolhardy Orm blunders on with his cultural fantasy, his fearless, well-muscled wife Frøya enthusiastically joins the men of another tribe in raiding and pillaging their own defenceless village.

In an interview with the Norwegian newspaper Dagbladet, actor Kåre Conradi (Orm), the 'sensitive viking' leader who fears war and goes to great lengths to introduce the viking village to culture, talked about how he believed it was high time to do something 'fun' with the vikings (2016). The result is a cosmetically plausible viking world. However, digging deeper into the comedy reveals a carnivalesque reversal in the Bakhtinian sense of the modern Norwegian welfare state (Bakhtin, 1963, p. 127). In what might be called an 'anti-welfare state,' we see a viking community that 
uncritically engages in acts of (sexual) violence and pillaging. The satire is clear, however, when conflicted warrior Arvid flippantly declares that 'taking stuff is so fun.' This gratuitous violence stands in stark contrast to the Norwegian self-image of a peace-promoting, generous nation (Skånland, 2014) whose history lies outside of European imperialism (Gullestad, 2005). The comedy also spoofs the Norwegian welfare state's focus on intergenerational fairness and helping the elderly live fulfilled lives. This occurs when Orm's mismanagement of the village's resources leads village elders to engage in the senecidal Ættestup ritual, throwing themselves, or being thrown, to their deaths when they were no longer able to lead independent lives or contribute resources to the village - a potential solution to historical shortcomings in the food supply.

Samurai Shifters takes on the concerns of work relocations and downsizings, controversial issues in Japan since the 1980s. Yet, sudden relocations were also common in the Edo period involving the same stresses, 'unexpected notice, an unfamiliar destination, limited time and funds,' as such moves do today (Haneda, 2019, para. 1). The dilemma of Samurai Shifters starts as the Lord of the Himeji domain is given two months' notice to shift an entire clan of several thousand warriors and their families to a new territory $600 \mathrm{~km}$ away. The new territory is half their current land size; moreover, they must make this move with limited resources and reduced manpower. This herculean and unpopular task is delegated to film's unlikely hero, Harunosuke Katagiri, a librarian and recluse, who prefers the company of books to people. Katagiri is expected to develop a master plan for the entire relocation, as well as to dismiss over half of the clan's samurai. With no prior experience and extreme lack of social skills, Katagiri's only desire is to escape. As luck would have it, however, he must eventually accept his new position despite his reluctance. The story evolves as Katagiri enlists the help of the loudmouth swordsman Genemon Takamura and the strong-minded Miss Oran, the daughter of the former relocation officer, to develop ingenious downsizing and relocation strategies. As he gains experience, Katagiri gradually earns the respect of fellow clansmen, impressing them with his honesty, empathy and egalitarian principles, in what increasingly plays out as a tongue-in-cheek riposte to the rigid hierarchical frameworks of contemporary Japanese working life.

In what follows we examine the ways in which comedy makes a statement about the current state of masculinity. We argue that the humour here depends on spectators' recognition of the difficulties associated with being a man in Norway and Japan today.

\section{Hikikomori masculinity and the pressures of Samurai-Salaryman life}

The opening scenes of Samurai Shifters confirm Katagiri's status as an unlikely hero. A reclusive librarian, his cloistered lifestyle and paralysing 
shyness resonate with the tensions of modern-day hikikomori masculinity. The hero's embodiment of the tragic social misfit is playfully communicated through the teasing banter that his friend Genemon Takamura engages in, poking and prodding him to take on his new role as relocation officer. At the same time, the pressure he is put under by the clan to accept the new job after initially balking at the task and his ultimate inability to refuse his superior's orders leads to his feelings of powerlessness. This sense of having no recourse vividly stages the pressures of the modern-day salaryman.

Hikikomori as a social phenomenon has been observed amongst Japanese young people, mostly young men, since the 1970s. It has gained even more attention since the late 1990s: 'Hikikomoru is a compound verb made up of the two characters for "to pull back" [hiku] and "to seclude oneself" [komoru]' (Kato et al., 2019, p. 427). The term hikikomori refers to individuals who have withdrawn from the group, whether school or the workplace, for months or even years, spending most of the day alone inside their home (Kato et al., 2019, p. 427). The opening narration of Samurai Shifters draws on viewers' familiarity with this phenomenon, foregrounding Katagiri as a 'hikikomori samurai.' We meet this paradoxical figure of the librarian-hikikomori anti-hero in the heart of his place of refuge, his library:

Narrator: The hero of this story is a librarian. The book this young man is now reading is a documentation of the Takeda clan's military strategies. (Inudô, 2019)

The film's journey will thrust the hapless Katagiri, nicknamed 'the snail' and 'shut-in' by his fellow clansmen, out of his closeted cocoon and into the limelight. When Katagiri's friend Genemon Takamura breaks the news to him that he is the favoured candidate for leading the massive relocation project, Katagiri is shocked. Here, the references to 'sunlight' and to Katagiri's response to the call of the outside world evoke the closeted interior lives of hikikomori (Inudô, 2019).

Genemon Takamura: I know a man who is perfect for the job.

Harunosuke Katagiri: Who is that?

Genemon Takamura: It's Snail. Come! It's time to get out into the sunlight.

Harunosuke Katagiri: Leave me alone! No! Ha, it's too bright! My eyes... my eyes! I...I am not good at talking to people!

While sociological discourses often understand hikikomori as 'passive objects' (Overell, 2018, p. 209), they can also be seen as 'wilful subjects,' who refuse to meet social obligations (Ahmed, 2014, as cited in Overell, 2018, p. 206). As such they can be read as queering normative masculinity in Japan, in the sense Sarah Ahmed ascribes to someone who deviates from given modes of being in the world (Ahmed, 2014, as cited in Overell, 2018, 
p. 210). The wilful subject is 'perverse and irritating' (Ahmed, 2014, p. 17). Katagiri embodies the contradiction of the hikikomori, appearing as a passive recluse obsessed with book learning and at the same time wilfully refusing to take on the job offer. He makes his refusal clear in words, but also by trying to run away. He only concedes to take the position when he is given the ultimatum to either accept the role or commit seppuku, a form of Japanese ritual suicide by disembowelment. Rosemary Overell argues that hikikomoris can be understood as 'queer subjects who are out of place and pace with the dominant heteronormative masculinist culture of contemporary Japan' (2018, p. 206). As we will see, as with other Katagiri hikikomori dramas, such as Train Man/Densha Otoko based on the purportedly true account of 23-year-old hikikomori's heroic intervention to stop harassment of a young women on a train, the lonely recluse moves from the margins and finds his way back into society.

At the same time, the Herculean task Katagiri is assigned brings into focus another emblematic symbol of modern Japan - the salaryman. The stereotypical salaryman figure is associated with an all-consuming, intensive workload alongside the demands to perform 'loyalty, diligence, dedication, and self-sacrifice' (Dasgupta, 2017, p. 40). The apparent impossibility of Katagiri's task, combined with his sense of powerlessness, the burden of his friends' and fellow clansmen's expectations, and the multiple logistical and financial pressures the task will involve function as a millstone around his neck. This professional salaryman-type burden is so heavy around the neck of a shy librarian that it becomes comical, especially, as we will see, as Katagiri takes it on in such a way as to destabilise the hierarchical underpinnings of masculine leadership on which they are founded.

\title{
Tidying up with Katagiri: The Marie Kondo School of Samurai Masculinity
}

\author{
\& Sorting, throwing, giving away \\ Packing, handing, finish in time \\ (Inudô, 2019)
}

As Katagiri starts to embrace his new role, his unconventional leadership style plays with gendered ideas about domesticity. As he begins to work out ways for the clan to downsize in anticipation of moving to a smaller territory, he comes up with a 'novel' decluttering strategy, amusingly reminiscent of modern day Japanese domestic trends. Inudo himself confirms that this strategy is a 'cheeky' reference to the philosophy of Japanese decluttering expert Marie Kondo, whose 2016 cult bestseller Spark Joy and Netflix Show Tidying up with Marie Kondo (2019) are all about 'throwing away anything that does not spark joy' (Pringle, 2019). In Samurai Shifters, the clansmen homes end up being Marie Kondo-ed, in a move that turns 
these samurai warriors into reluctant domestic goddesses. The Marie Kondo scene takes place when Katagiri comes up with the bright idea of asking all the local clansmen to get rid of any possessions that they do not need. He suggests they eliminate all objects that 'no longer spark joy,' a direct reference to Kondo's philosophy. In the spirit of egalitarianism, he decides to lead by example, turning on his own possessions and burning dozens of books from his personal library.

However, Katagiri's order to de-clutter does not 'spark joy' in all the clansmen. One member of the clan insists that he cannot comply with the order because his collections are extremely valuable. Demonstrating his newfound quick-wittedness, Katagiri puts the clansman's dependency on his possessions to the test. He covers up everything in the man's room and then asks him to make a list of all his possessions, now out of sight. Katagiri then orders all the valuables which do not appear on the list to be thrown away. The implication is that if that you cannot remember your possessions, then you do not need them. Mimicking the familiar resistance of TV hoarders, the clansman begs Katagiri to relent, while the former holds his ground with Marie Kondo-like self-assurance, substituting the rhetoric of joyfulness to that of attachment (Inudô, 2019):

Clansman: Wait! That one came from China and is priceless!

Katagiri: But you didn't remember it. It means that you felt no attachment to it. So, you don't need it.

As Katagiri is again reinvented, this time as a Samurai Marie Kondo, the film playfully de-couples domestic preoccupation from the world of women, poking fun at established gendered divisions of labour within the Japanese home. The scene produces an imagined comical juxtaposition between the rough and ready clansmen and the 'petite' Marie Kondo. At the same time, the idiocy of tossing valuable antiques represents a playful critique of the more extreme dimension of Kondo's one-size-fits-all philosophy. While the implied ludicrousness of the idea of men tidying up may appear misogynistic, the scene also sanctions such behaviour in the sense that it is initiated by the film's new hero.

\section{The caring sharing leader: Vikings and Samurais in a double-bind}

Season one of Norsemen exposes workplace expectations that place men in a double-bind. Even vikings are simultaneously and humorously expected to be both ambitious leaders with a clear vision and sensitive to relational issues among their subordinates. Returning momentarily to the opening sequence that stages Rufus's arrival in Norheim, we see Chieftain Olav returning to the settlement after several years of raiding and pillaging. He brings back to the village a Roman slave (Rufus), who is exceptionally cultured and ill-prepared for the lack of sophistication he encounters among 


\section{Jennifer Branlat and Priscilla Ringrose}

the vikings. As the ship approaches Norheim, Rufus hesitantly voices criticism with respect to the lack of comfort during the journey and the work and salary conditions he will find in Norheim. In a manner that reveals a misrecognition of his own position and resonates with modern management culture, he criticises the information flow aboard the overcrowded ship (Helgaker \& Torgersen, 2016):

Rufus:

\section{Chieftain Olav:}

Rufus:

Chieftain Olav:

Rufus:

Chieftain Olav (turns to Arvid): Arvid:

\section{Chieftain Olav:}

Not to complain, but I think the flow of information here on this boat is extremely arbitrary. And that's totally uncalled for, when we're so crammed together in such a small craft. I didn't know until yesterday that we were even going to Norway.

So, you think the information flow is under par?

Yes.

So, here's some information for you.

Finally! [Chieftain Olav punches Rufus in the nose] Ow, ow! Did you see that? Did everyone see that? There's something seriously wrong with my nose!

Was that a bit too much?

No, you're the chieftain. Aren't you supposed to be a little like that when you're in charge? A little crazy.

But it's not really me, that fear-based leadership style stuff. It doesn't feel right.

The scene's comic relief unravels at different levels. Olav's unexpected punch fits in with viewers' expectations about the vikings and their lack of diplomacy as well as viking-era power relations between master and slave. The Chieftain's unexpected self-doubt and soul-searching, however, belong more to the realm of the 'soft' and non-confrontational leadership style suited to the flat organisational structure of most contemporary Norwegian organisations. During this sequence, the spectator is drawn to see Olav as struggling to develop a leadership style with just the right balance of fear and feelings.

As Katagiri plans and executes the relocation, the film continues to cast a playful light on the overbearing and unequal practices of the present-day corporate culture. Yet, it also showcases Katagiri as an alternative type of leader. In the end, our hero, the reclusive hikikomori, faced with the multiple pressures of a salaryman's endless debt to the firm and obedience to his 
superiors, is reformed. He is intent on building team spirit, is not afraid of his dependence on others and is determined to call out the classist practices of his predecessors. As such, Katagiri symbolises the best of both worlds - a leader who can take on an enormous task and but who, at the same time, remains a sensitive soul.

Katagiri's egalitarian mindset incites explicit comment by other clansmen. When Oran discusses the mistreatment her father (the lowerclass former relocations officer and Katagiri's predecessor) suffered at the hand of his own boss, this becomes the occasion for Genemon Takamura to praise Katagiri's egalitarian mindset in comparison (Inudô, 2019):

Genemon Takamura: You must be the daughter of Itagaki [former magistrate in charge of relocation].

Oran: Yes

Genemon Takamura: Sajima [bureaucrat] always took credit for the accomplishment of Itagaki and advanced in his career without actually working. I detest that kind of attitude. On the other hand, Katagiri has never pushed people aside. He treats people equally, regardless of their position and class. I admire that.

This favourable comparison is further emphasised by Katagiri's actions when it is his turn to find out that all Itagaki's achievements were credited to his superiors because of his lower-class status. Katagiri then makes a point of going to Itagaki's grave to apologise, an act which earns him the respect of Oran, who was previously unwilling to pass on her father's strategic knowledge to him because of the unfair way her father had been treated. Oran's capitulation then becomes the mechanism for showcasing Katagiri's dependence on a woman - that is to say on the knowledge Oran gained from her father, another step in the road of egalitarian leadership. This same egalitarian spirit is demonstrated when the head of accounts urges Katagiri to take loans from merchants with no intention to pay them back. Katagiri makes it clear that he objects to stealing hard-earned money from ordinary people just because he is entitled to do so as a 'superior' samurai. Embodying a new masculinity, Katagiri continually challenges classist structures and privilege. He even suggests that the samurai abandon their normal privileges and carry their own bags when travelling.

Finally, one of the final scenes of the movie, a rollicking battle scene, demonstrates that successful outcomes in leadership ultimately do not depend on a male top dog. Rather the scene affirms collaborative practices, in which each and every member of the team counts equally. The battle scene opens when Katagiri's travelling group encounters enemy agents disguised as fishermen. As the enemy threatens to overwhelm them, the wisdom of Katagiri's team philosophy is borne out - men, women and children work together to outwit the imposters. Takamura grabs a massive outsize sword, 


\section{Jennifer Branlat and Priscilla Ringrose}

swirling it round with acrobatic dexterity, while a child strategically aims a slew of porcelain plates at the oncoming attackers, both sowing terror in their wake. But Katagiri's strategies come into play too. Since he had already encouraged the samurai to hone their physical skills so that they would be able to carry their own luggage, they are now well prepared to fight the good fight.

In the end our hero, the reluctant hikikomori, changes into a 'New Man' samurai. He exemplifies the best of the bushidō code, emerging as a trusty and wise leader who knows better than to rule by fear. Moreover, in the process, he conquers his own fears, embodying a masculinity hybrid that brings together the best of both worlds, the virtues of traditional bushido masculinity and a novel, more vulnerable manhood.

\section{Conclusion}

This chapter explores the ways in which Samurai Shifters and Norsemen playfully engage with contemporary issues of masculinity, a theme that has dominated debates on gender equality in both Norway and Japan in recent years. We asked: What dimensions of modern masculinities do these comedies explore? To what degree do these comedies uphold or challenge the prevailing social orders in Japan and Norway? Are there any similarities and differences that can be found in the representations of masculinity? Both Norsemen and Samurai Shifters use comedy to establish a frame for an alternative to 'serious' societal discussions about gender roles and gender equality, which tend to focus on men's shortcomings and reflect ambivalence about masculine roles in both the public and private spheres. Toying with recognisable stereotypical male figures, they bring current social tensions relating to men's domestic and working life to light. Samurai Shifters exposes the unbearable burdens of the salaryman, kicks the hikikomori back into society and imagines an idealised leader who represents the antithesis of corporate Japan and the best of bushidō values - all while poking fun at modern domestic obsessions. Norsemen goes further in exposing the persistent tensions and ambivalences of contemporary western masculinity, suggesting that masculine ideals are unachievable when considered as a whole: Reconciling work-related absences with family-building aspirations, the pressure to 'have it all' in terms of a meaningful personal life and career and the conflicted feelings of so-called New Managers who are supposed to embrace the tenants of sensitive leadership. Both comedies focus on the near-impossible imperatives of modern 'caring' masculinity and both depend heavily on viewers' recognition of modern experiences represented in the remote historical worlds. In order to partake in the humour, viewers must recognise their own social world - in particular, the contours, boundaries and 'excesses' of discourse surrounding New Manhood today. The primary difference between these comedies lies in Norsemen pushing viewers to laugh at a gender equality 'gone too far,' while the Japanese 
comedy light-heartedly affirms the potential in the egalitarian values that meet resistance in Japan's contemporary rigid social hierarchy. Both of these works affirm the essential role of humour in allowing us to step away and see the gender equality of our own social worlds from the outside, reflected in the metallic sheen of the samurai and vikings swords.

\section{References}

Ahmed, S. (2014). Willful subjects. Duke University Press.

Bakhtin, M.M. (1963). Problems of Dostoevsky's poetics. University of Minnesota Press.

Benioff, D. \& Weiss, D.B. (Creators). (2011-2019). Game of Thrones [Series]. HBO Entertainment.

Critchley, S. (2011). On bumour. Routledge.

Dancus, A. (2011). A father's body, a nation's heart-caregiving fathers in contemporary Norwegian film. NORA - Nordic Journal of Feminist and Gender Research, 19(2), 71-86.

Dasgupta, R. (2010). Globalisation and the bodily performance of 'cool' and 'uncool' masculinities in corporate Japan. Intersections: Gender and Sexuality in Asia and the Pacific, 23. http://intersections.anu.edu.au/issue23/dasgupta.htm

Dasgupta, R. (2013). Re-reading the salaryman in Japan. Routledge.

Dasgupta, R. (2017). Articulations of salaryman masculinity in Shôwa and PostShôwa Japan. Asia Pacific Perspectives, 15(1), 36-54.

Donnar, G. (2015). Male anxiety, inadequacy and victimhood: Insecure and immature men in recent Norwegian cinema. Journal of Scandinavian Cinema, 5(2), 155-168.

Gullestad, M. (2005). Normalising racial boundaries: The Norwegian dispute about the term neger. Social Anthropology, 13(1), 27-46.

Haneda, R. (2019). 'Samurai Shifters' is a comedy full of work efficiency, teamwork tips we can all instantly incorporate into our careers. Japanese Film Festival Magazine. https://jff.jpf.go.jp/read/column/3954/

Helgaker, J. \& Torgersen, J. (Creators). (2016-2020). Norsemen [TV series]. Norsk Rikskringkasting AS.

Hidaka, T. (2010). Salaryman masculinity: The continuity of and change in the begemonic masculinity in Japan. Brill.

Hinojosa, R. (2010). Doing hegemony: Military, men, and constructing a hegemonic masculinity. Journal of Men's Studies, 18, 179-194.

Inudô, I. (Director). (2019). Hikkoshi Daimyo!/Samurai Shifters [Film]. Shochiku.

Ishii-Kuntz, M. (2019). Japanese child caring men (ikumen) and achieving work-life balance. In U. Meier-Gräwe, M. Motozawa, \& A. Schad-Seifert (Eds.), Family life in Japan and Germany. Springer.

Kato, T.A., Kanba S., \& Teo, A.R. (2019). Hikikomori: Multidimensional understanding, assessment, and future international perspectives. Psychiatry and Clinical Neurosciences, 73(8), 427-440. https://doi.org/10.1111/pcn.12895

Kondo, M. (Executive Producer). (2016). Tidying up with Marie Kondo. The Jackal Group.

Marthinussen, L.C. (2018, 16 February). Kristofer Hivju: Det å være en samlet familie, veier tungt for meg - 'Game of Thrones'-stjernen åpner opp om 


\section{Jennifer Branlat and Priscilla Ringrose}

familielivet [Kristofer Hivju: Being a united family weighs heavily on me - 'Game of Thrones' star opens up about family life]. Se og Hør. https://www.seher.no/ kjendis/det-a-vaere-en-samlet-familie-veier-tungt-for-meg/69522911

Mulkay, M. (1988). On humour: Its nature and its place in modern society. Polity Press.

Overell, R. (2018). Queer will: Hikikomori as willful subjects. Inter-Asia Cultural Studies, 19(2), 206-219. https://doi.org/10.1080/14649373.2018.1463069

Pringle, G. (2019, 1 November). Isshin inudo: Life of samurai. Filmink. https:// www.filmink.com.au/isshin-inudo-life-samurai/

Raffield, B. (2019). Playing vikings: Militarism, hegemonic masculinities, and childhood enculturation in Viking Age Scandinavia. Current Anthropology, 60(6), 813-835.

Rappoport, L. (2005). Punchlines: The case for racial, ethnic, and gender humour. Praeger.

Roberson, J., \& Suzuki, N. (2003). Men and masculinities in contemporary Japan: Dislocating the salaryman doxa. Routledge.

Sandberg, E. (Director). (2019). Amundsen [Film]. SF Studios.

Skånland, Ø.H. (2014). Norway is a peace nation: A discourse analytic reading of the Norwegian Peace Engagement. Peacebuilding, 4, 23-45.

Sugimoto, Y. (2010). An introduction to Japanese society. Cambridge University Press.

Taga, F. (2006). Westernization or Hybridization?: Restructuring Japanese Hegemonic Masculinity in Globalization [Conference paper]. XVIII ISA World Congress of Sociology. Yokohama.

Taga, F. (2013). Review of the book 'Salaryman masculinity: The continuity and change in the hegemonic masculinity in Japan' by T. Hidaka. Contemporary Sociology, 42(3), 391-393.

Turner, G. (2006). Film as social practice (4th ed.). Routledge.

Vogel, E.F. (1963). Japan's new middle class: The salary man and his family in a Tokyo suburb. University of California Press. 